\title{
REVIEW
}

\section{Kisspeptin and fertility}

\author{
Saira Hameed, Channa N Jayasena and Waljit S Dhillo \\ Division of Diabetes, Endocrinology and Metabolism, Section of Investigative Medicine, Imperial College London, Hammersmith Hospital, 6th Floor \\ Commonwealth Building, Du Cane Road, London W12 0NN, UK \\ (Correspondence should be addressed to W S Dhillo; Email: w.dhillo@imperial.ac.uk)
}

\begin{abstract}
The kisspeptins are a family of peptide hormones, which in recent years have been shown to play a critical role in the regulation of the hypothalamic-pituitary-gonadal axis, thus in turn influencing fertility and reproduction. This review examines the physiological role of kisspeptin and the kisspeptin receptor in
\end{abstract}

the control of gonadotrophin and gonadal steroid hormone secretion and the implications of these findings with respect to fertility. In addition, the potential therapeutic use of kisspeptin in the treatment of reproductive disorders will be examined.

Journal of Endocrinology (2011) 208, 97-105

\section{Introduction}

Infertility affects up to one in six couples in the United Kingdom (Human Fertilisation and Embryology Authority 2009, http://www.hfea.gov.uk/infertility-facts.html\#1248). The currently available hormone-based treatments for infertility act through the manipulation of the hypothalamicpituitary-gonadal (HPG) axis at the level of GnRH or below. Although effective, these treatments also have a significant failure rate as well as an associated morbidity. The discovery of kisspeptin in 1996 and the subsequent identification of the kisspeptin receptor (previously known as G-protein-coupled receptor 54, GPR54) have added a new critical dimension to our understanding of the physiology of the HPG axis, reproduction and fertility (Lee et al. 1996, Clements et al. 2001). Mice and humans lacking kisspeptin receptor expression show a phenotype of hypogonadotrophic hypogonadism and consequent infertility (de Roux et al. 2003, Seminara et al. 2003). However, kisspeptin receptor knockout mice have normal levels of hypothalamic GnRH expression (Seminara et al. 2003) and normal GnRH neuronal morphology (Messager et al. 2005). These findings have been pivotal in the emergence of kisspeptin signalling as critical regulator of normal fertility, and future work may lead to the development of therapeutic use of kisspeptin in the treatment of reproductive disorders.

\section{Kisspeptin structure and distribution}

The kisspeptins are a family of RF peptide hormones, so named as the arginine-phenylalanine residues are present at the amino terminal (Arg-Phe-NH2; Clements et al. 2001,
Kotani et al. 2001). The kisspeptins are products of the KISS1 gene derived from the plasma proteolytic cleavage of the 145-amino acid gene product, the suffix denoting the number of amino acids. All of the kisspeptin fragments have a C-terminal decapeptide that is critical for biological activity, and all of the kisspeptin forms show similar agonist activity for kisspeptin receptor (Clements et al. 2001, Kotani et al. 2001, Ohtaki et al. 2001).

Kisspeptin is found in both the peripheral and the central nervous system (CNS). In the periphery, kisspeptin has been identified in the testis, ovary, anterior pituitary gonadotrophs, pancreas and small intestine (Ohtaki et al. 2001, Richard et al. 2008, Gaytan et al. 2009). However, peripheral expression of kisspeptin is highest in the placenta with maternal plasma levels of kisspeptin in the third trimester of pregnancy rising to 7000 -fold greater than in the non-pregnant state (Muir et al. 2001, Ohtaki et al. 2001, Horikoshi et al. 2003). It has been postulated that the function of kisspeptin production by the placenta may be to down-regulate the HPG axis during pregnancy. However, this is not in keeping with the finding that when kisspeptin-10 is centrally administered to pregnant rats, stimulation of the HPG axis is found to be preserved (Roa et al. 2006). Kisspeptin-10 inhibits trophoblast migration in human placental explants (Bilban et al. 2004). Plasma kisspeptin IR is elevated in patients with gestational trophoblastic neoplasia when compared with non-pregnant controls and falls during and after chemotherapy (Dhillo et al. 2006). Furthermore, levels of kisspeptin and kisspeptin receptor mRNA in placental tissue are increased in cases of gestational trophoblastic disease when compared with normal placental tissue (Janneau et al. 2002). Such observations have 
led to speculation that kisspeptin may act to regulate trophoblastic invasion of uterine tissue. However, patients with inactivating mutations of the kisspeptin receptor are able to undergo normal pregnancy after treatment with GnRH or gonadotrophin (Pallais et al. 2006). The function of placental kisspeptin signalling is therefore currently unknown; however, its presence may not be essential for placental function in humans.

Within the rodent CNS, both Kiss $1 \mathrm{mRNA}$ and kisspeptin protein are particularly highly expressed within the hypothalamus in the arcuate nucleus (ARC), anteroventral periventricular nucleus (AVPV) and periventricular nucleus (Gottsch et al. 2004). In primates including humans, hypothalamic KISS1 mRNA is predominantly found within the infundibular nucleus, which is the equivalent of the ARC in this order of mammals (Rometo et al. 2007).

\section{The kisspeptin receptor}

The kisspeptin receptor is a member of the rhodopsin family of seven transmembrane GPRs with structural similarities to the galanin receptor. However, it does not appear to bind galanin in vitro (Lee et al. 1999, Muir et al. 2001). Initially classified as an orphan receptor, the kisspeptin receptor (previously known as GPR 54) was found to be the cognate receptor for kisspeptin 5 years after the hormone was first described (Kotani et al. 2001, Muir et al. 2001, Ohtaki et al. 2001).

Within the CNS, the kisspeptin receptor is found within the hypothalamus but is also widely expressed within both cortical and subcortical regions (Lee et al. 1999). In the periphery, it is notably expressed in the placenta and by pituitary gonadotrophs (Muir et al. 2001, Richard et al. 2008).

\section{Kisspeptin stimulates the release of GnRH through action at the kisspeptin receptor, which in turn stimulates gonadotrophin release}

The GnRH neurons of primates, rodents and sheep are found in close apposition with kisspeptin neurons (Silverman et al. 1977, Barry 1979, Rance et al. 1994, Clarkson \& Herbison 2006). GnRH neurons express the kisspeptin receptor, and when kisspeptin is incubated with hypothalamic explants, it stimulates the release of $\mathrm{GnRH}$. This effect is not observed in kisspeptin receptor knockout mice (kiss $1 r^{-/-}$; d'Anglemont de Tassigny et al. 2008). The pivotal role of the kisspeptin receptor in kisspeptin-stimulated $\mathrm{GnRH}$ release is further demonstrated by the attenuation of the rise in plasma $\mathrm{LH}$ following kisspeptin administration in male mice and rats pre-treated with i.c.v. injections of a kisspeptin receptor (Roseweir et al. 2009).

I.c.v. administration of kisspeptin-52 to male rodents results in the expression of c-Fos (a well-established marker of neuronal activation) within the cell bodies of $\mathrm{GnRH}$ neurons.
In addition, GnRH neurons show an increase in firing rate in vitro following kisspeptin treatment. This effect is attenuated by the application of a kisspeptin receptor antagonist (Irwig et al. 2004, Liu et al. 2008, Roseweir et al. 2009). Furthermore, kisspeptin treatment results in a doseand time-dependent increase in GnRH mRNA levels in GnRH-secreting neuronal cell lines (Novaira et al. 2009).

Both i.c.v. and peripheral administration of kisspeptin result in a marked rise in plasma $\mathrm{LH}$ and to a lesser extent FSH in several mammalian species including rats, mice, sheep, monkeys and humans. This effect is abolished in GPR $54^{-1-}$ mice (Gottsch et al. 2004, Thompson et al. 2004, Dhillo et al. 2005, 2007, Messager et al. 2005, Seminara et al. 2006, Caraty et al. 2007). The effect of kisspeptin on gonadotrophin release is likely to be due to kisspeptin stimulation of $\mathrm{GnRH}$ release into the portal circulation, which in turn stimulates the release of LH and FSH from the gonadotrophs of the anterior pituitary gland. Evidence for this includes the abolition of the kisspeptin-induced gonadotrophin rise following pretreatment with a $\mathrm{GnRH}$ antagonist.

These findings are consistent with the phenotype of hypogonadotrophic hypogonadism of $k i s s 1 r^{-1-}$ and kiss $1^{-1-}$ null mice (de Roux et al. 2003, Seminara et al. 2003, d'Anglemont de Tassigny et al. 2007). These mice have normal levels of hypothalamic GnRH. As expected, kisspeptin administration to Kiss $1^{-/-}$mice results in gonadotrophin release, but this effect is not observed in Gpr $54^{-1-}$ mice (de Roux et al. 2003, Seminara et al. 2003, Messager et al. 2005, d'Anglemont de Tassigny et al. 2007). Thus, evidence suggests that kisspeptin is the major ligand for the kisspeptin receptor.

\section{Kisspeptin may also act directly on pituitary gonadotrophs to stimulate gonadotrophin release}

Some lines of evidence point towards a direct effect of kisspeptin on the gonadotrophs of the anterior pituitary gland, stimulating the release of LH and FSH. Both the Kiss 1 and Kiss $1 R$ genes are expressed in pituitary gonadotrophs, and in vitro exposure of pituitary cells and tissue explants to kisspeptin results in the dose-dependent release of LH (Kotani et al. 2001, Navarro et al. 2005, Gutierrez-Pascual et al. 2007, Richard et al. 2008). Furthermore, in ovariectomised female rats, there is a fall in the expression of Kiss 1 mRNA within gonadotrophs, which can be prevented by the administration of oestradiol ( $\mathrm{E}_{2}$; Richard et al. 2008). These data suggest that circulating sex steroids may be required for pituitary Kiss 1 expression. This is consistent with the observation that circulating levels of $\mathrm{E}_{2}$ modulate responsiveness of pituitary gonadotrophs to GnRH (Knobil et al. 1980).

Nevertheless, kiss $1 r^{-1-}$ mice that show a phenotype of hypogonadotrophic hypogonadism have preserved gonadotroph function as evidenced by an appropriate response to exogenous GnRH (Seminara et al. 2003). In addition, i.v. administration of kisspeptin fails to stimulate LH release in 
GnRH-replaced, ovariectomised, hypothalamic-pituitarydisconnected ewes. Furthermore, the pre-treatment of male monkeys with a GnRH antagonist results in the failure of administered kisspeptin to stimulate an LH rise (Plant et al. 2006, Smith et al. 2008).

The role of kisspeptin within the pituitary is currently unknown. In vivo and ex vivo evidences suggest a stimulatory role of kisspeptin within the anterior pituitary. However, pituitary kisspeptin signalling does not appear critical for the robust stimulation of gonadotrophin release observed following kisspeptin administration in vivo. Hence, kisspeptin signalling within the pituitary may have a regulatory role on gonadotrophin function, which is distinct to its better characterised role within the hypothalamus.

\section{Kisspeptin plays a key role in mediating gonadal steroid feedback to the hypothalamus}

Steroid hormones produced by the gonads feed back to the hypothalamus exerting a positive or a negative regulatory effect on GnRH production and release. The oestrogen receptors (ERs) are transcription factors, which exist as two isoforms, $\mathrm{ER} \alpha$ and $\mathrm{ER} \beta$. These receptors bind to specific DNA sequences known as oestrogen-response elements found in the promoter region of oestrogen-responsive genes, resulting in the activation or suppression of gene transcription.

During most of the menstrual cycle, oestrogen suppresses gonadotrophin secretion, but at mid-cycle, the effect of oestrogen on the HPG axis changes to a potent positive feedback effect, leading to a surge in the plasma LH and ovulation. Increasing evidence suggests that hypothalamic kisspeptin signalling plays a critical role in the generation of the pre-ovulatory LH surge, which is necessary for normal fertility. Evidence for this comes from ovariectomised GPR 54 and Kiss 1 null mice treated with oestrogen and progesterone, which fail to mount an LH surge unlike their wild-type litter mates (Dungan et al. 2007, Clarkson et al. 2008). In addition, infusion of a monoclonal anti-rat kisspeptin antibody into the pre-optic area (POA), which contains GnRH cell bodies, leads to the complete blockade of the pre-ovulatory LH surge in oestrogen-treated ovariectomised female rats (Kinoshita et al. 2005). Lastly, continuous i.c.v. administration of a kisspeptin antagonist to female rats in the morning of oestrous until the afternoon of the following pro-oestrous prevents the pre-ovulatory LH surge (Pineda et al. 2010).

$E R \alpha$ has been shown to be critical for the positive feedback effect of oestrogen, which results in the female mid-cycle LH surge. Adult female rodents pre-administered with an ER $\alpha$ antagonist fail to ovulate or undergo a pre-ovulatory $\mathrm{LH}$ surge and have blunted LH response following administration of kisspeptin-10 (Roa et al. 2008). Furthermore, ovariectomised, oestrogen-replaced, neuron-specific $E R \alpha$ null mice are infertile. It is not known whether such mice have altered levels of Kiss 1 expression, but they fail to generate a pre-ovulatory LH peak despite having normal basal levels of LH (Wintermantel et al. 2006). Interestingly, the preovulatory LH surge is preserved in $E R \beta$ knockouts (Wintermantel et al. 2006). GnRH neurons express ER $\beta$ but not $\mathrm{ER} \alpha$, which implies that the mid-cycle positive regulation of $\mathrm{GnRH}$ release by oestrogen is mediated by a separate population of $\mathrm{ER} \alpha$-expressing neurons with afferent input to GnRH neurons (Hrabovszky et al. 2000). Dual in situ hybridisation studies have revealed the co-expression of Kiss 1 and ER $\alpha$ mRNA in the AVPV and the ARC. In addition, work using neuronal viral retrograde tracing in mice has demonstrated ER $\alpha$-expressing neurons in the AVPV and ARC with afferent input to GnRH neurons (Smith et al. 2005, Wintermantel et al. 2006). In female rats, Kiss $1 \mathrm{mRNA}$ expression in the AVPV peaks during the evening of pro-oestrous but falls to a nadir in the ARC (Smith et al. 2006b). Kiss 1 neurons in the AVPV show high levels of c-Fos expression during the LH surge, while c-Fos expression at dioestrous is virtually absent (Smith et al. 2006b). Conversely, c-Fos is almost undetectable in the ARC at pro-oestrous (Smith et al. 2006b). Lastly, in female mice following ovariectomy, Kiss 1 expression in the AVPV falls but is increased following oestrogen replacement in these animals. Interestingly, the opposite pattern is observed in the ARC (Smith et al. 2005).

Taken altogether, these findings suggest that $\mathrm{E}_{2}$ within ER $\alpha$-expressing kisspeptin neurons in the AVPV positively regulates $\mathrm{GnRH}$ neurons culminating in the pre-ovulatory LH surge. However, ER $\alpha$-expressing kisspeptin neurons in the ARC respond to oestrogen stimulation by inhibiting GnRH production and release (Fig. 1). This feed forwardfeedback control on GnRH release by gonadal steroids is critical for normal fertility.

\section{Kisspeptin neurons in the ARC co-express other neuropeptides, which regulate the HPG axis}

Kisspeptin neurons in the ARC co-express the neuropeptides neurokinin $\mathrm{B}(\mathrm{NKB})$ and dynorphin, and this co-localisation is highly conserved in several mammalian species including humans (Goodman et al. 2007, Rance 2009, Hrabovszky et al. 2010). Dynorphin is an endogenous opioid peptide, which plays a role in the progesterone-mediated negative feedback control of GnRH release, while NKB is a member of the substance P-related tachykinin family (Goodman et al. 2004, Krajewski et al. 2005). The receptor for NKB is tachykinin neurokinin 3 receptor (NK3R), which is expressed on GnRH neurons (Todman et al. 2005).

Recently, it has been reported in humans that lossof-function mutations in the gene encoding NKB (TAC3) or the gene encoding NK3R (TAC3R) result in normosmic hypogonadotrophic hypogonadism and pubertal failure. This phenotype is remarkably similar to rodent and human models of defective kisspeptin signalling (de Roux et al. 2003, 


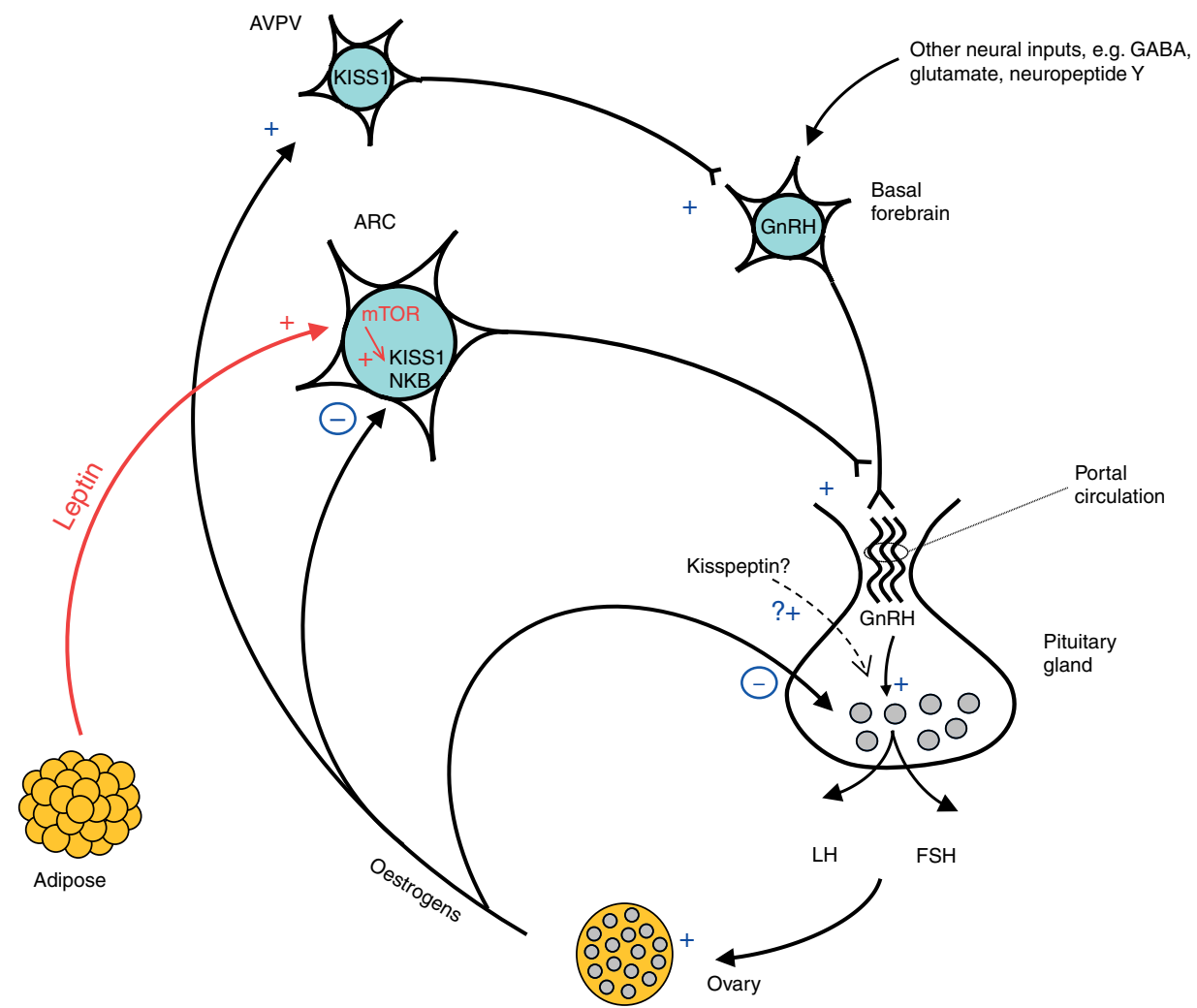

Figure 1 Diagram of kisspeptin signalling within the female central nervous system. KISS1-expressing neurons within the hypothalamic arcuate nucleus (ARC; equivalent to the infundibular nucleus in primates) are negatively regulated by oestrogen and inhibit GnRH release. KISS1-expressing neurons within the hypothalamic anteroventral periventricular nuclear (AVPV) are positively regulated by oestrogen and stimulate GnRH during the pre-ovulatory surge. Kisspeptin may also have a direct modulatory effect on pituitary LH and FSH release. KISS1 neurons in the ARC co-express neurokinin B (NKB), which stimulates $\mathrm{LH}$ and FSH release in a GnRH-dependent manner. Leptin signalling has a permissive effect on kisspeptin signalling within the ARC, which may be mediated by the mammalian target of rapamycin (mTOR; also known as mechanistic target of rapamycin, MTOR) pathway.

Seminara et al. 2003, d'Anglemont de Tassigny et al. 2007, Guran et al. 2009, Topaloglu et al. 2009).

Kisspeptin neurons in the ARC project to GnRH neurons. The association of NKB and kisspeptin within kisspeptin neurons may be suggestive of a synergy between the two neuropeptides in the regulation of the HPG axis. For example, it is known that the expression of both peptides is inhibited by $\mathrm{E}_{2}$. In addition, in post-menopausal women, the distribution and morphology of the hypertrophied KISS1-positive neurons in the infundibular nucleus are similar to that of NKB-expressing cells (Rometo et al. 2007, Navarro et al. 2009).

Until recently, the effect of $\mathrm{NKB}$ on reproductive hormone release had been inconclusive with conflicting results from studies in sheep and rodents (Jayasena \& Dhillo 2010). However, recently it has been reported that i.v. administration of $\mathrm{NKB}$ or an NKB agonist to male monkeys results in a potent stimulation of $\mathrm{LH}$ release, an effect that is abolished by pre-treatment with a GnRH antagonist (Ramaswamy et al. 2010). Interestingly, repetitive administration of $\mathrm{NKB}$ is not associated with a sustained pattern of $\mathrm{LH}$ release (Ramaswamy et al. 2010). Furthermore, monkeys remain responsive to kisspeptin injection despite losing responsiveness to NKB following repetitive administration. This suggests that NKB stimulates GnRH release in a kisspeptinindependent manner. It is not known whether animals may respond to $\mathrm{NKB}$ despite losing responsiveness to kisspeptin following chronic administration; such an observation would suggest NKB and kisspeptin to have parallel influences of GnRH release.

\section{A role for kisspeptin signalling in pubertal development and seasonal reproductive activity}

During puberty, the immature mammal develops adult physical and hormonal characteristics rendering it fertile and capable of reproduction. Juvenile kiss $1 r^{-1-}$ and kiss $1^{-/-}$mice and humans with inactivating kisspeptin receptor mutations fail to enter puberty (de Roux et al. 2003, 
Seminara et al. 2003, d'Anglemont de Tassigny et al. 2007); these observations therefore suggest that kisspeptin signalling plays a critical role in the onset of puberty.

Further evidence for the importance of kisspeptin signalling in the onset of puberty comes from studies of immature female rats administered twice daily i.c.v. injections of kisspeptin from postnatal day 26 to day 31 (Navarro et al. 2004). This results in precocious vaginal opening, increased uterine weight and raised plasma $\mathrm{LH}$ and $\mathrm{E}_{2}$ levels relative to vehicle-treated controls. These findings complement the report of central precocious puberty in an 8-year-old girl due to an activating mutation of KISS1R (Teles et al. 2008).

At postnatal day 10, kisspeptin-expressing neurons in the AVPV are not detectable in either male or female mice. However, these become apparent, lying in close apposition to GnRH neurons, from postnatal day 25, reaching adult levels by the onset of puberty at postnatal day 31 (Clarkson \& Herbison 2006). In support of these findings, the expression of KISS1 mRNA in the mediobasal hypothalamus (MBH) of agonadal male rhesus monkeys has been found to be significantly greater in the pubertal group than in the juvenile cohort (Shahab et al. 2005). Similarly, in female monkeys with intact gonads, a threefold increase in KISS1 mRNA expression is observed in the $\mathrm{MBH}$ in early pubertal animals that in a juvenile group (Shahab et al. 2005).

Kisspeptin is also implicated in seasonal regulation of reproductive activity in seasonal breeders. In Syrian hamsters, hypothalamic Kiss 1 expression is high during long day conditions (associated with sexual activity) and reduced during short day conditions (associated with a quiescence of sexual activity); furthermore, administration of kisspeptin-10 to these animals restores testicular weight and testosterone release (Revel et al. 2006, 2007). Sheep display seasonal sexual activity during short day conditions. KISS1 expression within the ARC is increased under short day conditions in ovariectomised ewes, but no seasonal change in KISS1 expression is detected within the POA (Clarke et al. 2009).

These findings suggest that kisspeptin acts as an essential gatekeeper to the onset of puberty and consequent fertility in several mammalian species. Furthermore, kisspeptin may play a role in the seasonal regulation of reproductive activity in Syrian hamsters and sheep.

\section{Kisspeptin provides a link between nutritional status and fertility}

It has long been recognised that an intimate relationship exists between nutritional status and fertility. Leptin is a peptide hormone synthesised and secreted by adipocytes conveying information about body energy stores and nutritional status (Zhang et al. 1994, Pelleymounter et al. 1995). The level of circulating leptin is proportional to fat mass and falls in both mice and humans following weight loss (Maffei et al. 1995). The leptin-deficient $o b / o b$ mouse is a well-established model of hypoleptinaemia (Zhang et al. 1994). These mice have delayed puberty and are infertile as a consequence of hypogonadotrophic hypogonadism. Interestingly, a similar phenotype of hypogonadotrophic hypogonadism is also present in humans with mutations of leptin or its receptor and in women with hypoleptinaemia as a consequence of low body weight (Coleman 1978, Clement et al. 1998, Farooqi et al. 1999, Welt et al. 2004). Leptin therapy in hypoleptinaemic mice and humans reverses these reproductive abnormalities. In addition, when leptin is administered to juvenile wild-type mice, this accelerates the onset of puberty (Chehab et al. 1996, 1997, Ahima et al. 1997, Farooqi et al. 1999, Welt et al. 2004).

The leptin receptor $(\mathrm{Ob}-\mathrm{Rb})$ is not expressed by $\mathrm{GnRH}$ neurons of the hypothalamus. However $O b-R b$ mRNA is found in $40 \%$ of Kiss $1 \mathrm{mRNA}$-expressing cells of the ARC (Smith et al. 2006a). The expression of Kiss $1 \mathrm{mRNA}$ in the ARC of $o b / o b$ mice is reduced in comparison with wild-type mice. Interestingly, although kisspeptin mRNA in the ARC of $o b / o b$ mice is significantly increased following leptin treatment, its expression is not restored to that of the wildtype controls (Smith et al. 2006a).

The expression of Kiss1 mRNA has been shown to be influenced by nutritional status. In pre-pubertal rats, which have been food deprived for $72 \mathrm{~h}$, the hypothalamic expression of Kiss 1 mRNA is markedly reduced (Castellano et al. 2005). In a model of chronic undernutrition in prepubertal rats, daily i.c.v. administration of kisspeptin from postnatal day 30 to 37 restores the delayed vaginal opening of these animals and increases the suppressed levels of plasma $\mathrm{LH}$, FSH and $\mathrm{E}_{2}$ (Castellano et al. 2005).

The ARC contains discrete subpopulations of first-order leptin-responsive neurons. One subpopulation expresses the orexigenic peptide neuropeptide Y (NPY), while another expresses the anorectic peptide $\alpha$-melanocyte-stimulating hormone $(\boldsymbol{\alpha}-\mathrm{MSH})$, which is derived from pro-opiomelanocortin (POMC; Cheung et al. 1997, Broberger et al. 1998). Using double-label fluorescent immunohistochemistry, kisspeptin fibres in ewes have been shown to be in close apposition with ARC NPY and POMC neurons (Backholer et al. 2010). I.c.v. administration of an $\boldsymbol{\alpha}$-MSH-like agonist to ewes increases KISS1 mRNA in the POA and results in a rise in plasma LH (Backholer et al. 2009). Conversely, the orexigenic peptide melanin-concentrating hormone, which is highly expressed in the lateral hypothalamus, inhibits the stimulatory effects of kisspeptin on GnRH neurons (Wu et al. 2009).

Mammalian target of rapamycin protein (mTOR; also known as mechanistic target of rapamycin, MTOR) is another regulator of energy homeostasis, which has been shown to influence kisspeptin signalling. mTOR is a ubiquitously expressed serine-threonine protein kinase, which plays a vital role in the regulation of cell growth and differentiation (Schmelzle \& Hall 2000). When nutrient availability is low, mTOR activity falls thus inhibiting the high-energy demand cell cycle. Interestingly, i.c.v. administration of leucine (which stimulates mTOR signalling) leads to an increase in plasma $\mathrm{LH}$ in female peri-pubertal rats 
(Cota et al. 2006, Roa et al. 2009). Conversely, when mTOR activation is blocked (by rapamycin), the expression of Kiss 1 mRNA in the ARC becomes almost undetectable, and plasma levels of LH fall (Roa et al. 2009).

Reproduction is a highly energy demanding process, and during food deprivation the HPG axis is down-regulated in order to conserve energy. In summary, the findings presented above demonstrate a key role for hypothalamic kisspeptin as a link between nutritional status and fertility.

\section{Could kisspeptin offer a novel therapy for the treatment of fertility disorders?}

As our understanding of the biology of the kisspeptin signalling system grows, it is becoming increasingly tempting to speculate on the possible therapeutic use of kisspeptin in the treatment of fertility disorders. Infertility affects up to one in six couples in the United Kingdom, and although effective, both the hormonal and surgical therapies, which are currently employed are not without significant side effects and failure rates (National Institute for Health and Clinical Excellence 2004, Human Fertilisation and Embryology Authority 2009, http://www.hfea.gov.uk/infertility-facts.html\#1248).

When administered to healthy male subjects, i.v. infusion of kisspeptin results in a significant increase in plasma LH, FSH and testosterone (Dhillo et al. 2005). S.c. injection of kisspeptin to healthy pre-menopausal female subjects elicits a marked rise in $\mathrm{LH}$, which is most pronounced in the preovulatory phase of the menstrual cycle (Dhillo et al. 2007). This finding sits well with the animal studies reviewed above, which suggest an essential role for kisspeptin in the generation of the LH surge.

Kisspeptin has been administered to humans by s.c. and i.v. injection without any observed adverse effects (Dhillo et al. 2005, 2007). In particular, kisspeptin has not been shown to cause changes in heart rate or blood pressure, which is important in view of the vasoconstrictor properties of kisspeptin that have been demonstrated in vitro (Mead et al. 2007, Nijher et al. 2010).

When kisspeptin is administered twice daily s.c. injection to infertile women with functional hypothalamic amenorrhoea (HA) due to low body weight, it effectively stimulates a rise in plasma gonadotrophins (Jayasena et al. 2009). This effect is most marked following the first injection of kisspeptin and is significantly diminished after 2 weeks of treatment. However, biweekly administration of kisspeptin results in a sustained gonadotrophin response to kisspeptin (Jayasena et al. 2010). Furthermore, it has been shown that in women with $\mathrm{HA}$, the LH response to injected kisspeptin is fourfold greater than that of healthy female subjects studied in the follicular phase (Jayasena et al. 2009). This may be due to an enhanced responsiveness to kisspeptin in women with HA or increased pituitary sensitivity to the effects of GnRH.

Gonadotrophin injections provide the current mainstay of infertility therapy (Elchalal \& Schenker 1997). It is therefore interesting to consider if kisspeptin-based therapies would offer any potential advantages over existing therapies. Kisspeptin acts by stimulating endogenous hypothalamic GnRH release, which in turn triggers endogenous pituitary gonadotrophin release (Irwig et al. 2004, Thompson et al. 2004, Shahab et al. 2005). Kisspeptin therapy might therefore stimulate a more natural pattern of reproductive hormone release than existing therapies. Furthermore, the stimulation of endogenous gonadotrophin release by kisspeptin may be predicted to confer a lower risk of ovarian hyperstimulation syndrome associated with exogenous gonadotrophin injections (Elchalal \& Schenker 1997). More data are needed to test if such potential benefits would exist over current therapies for infertility.

\section{Concluding remarks}

Over the past decade, our increasing insight into the biology of the kisspeptin pathway has significantly added to our understanding of the physiology and pathophysiology of the HPG axis. Kisspeptin has now been safely and successfully used in both healthy and infertile human subjects, and it is possible that in the future the manipulation of kisspeptin signalling may be used in the treatment of reproductive disorders.

\section{Declaration of interest}

The authors declare that there is no conflict of interest that could be perceived as prejudicing the impartiality of the research reported.

\section{Funding}

SH is supported by a Medical Research Council Clinical Research Training Fellowship. CNJ is supported by an NIHR Clinical Lectureship and a Wellcome Trust Clinical Research Training Fellowship. WSD is supported by a HEFCE Clinical Senior Lecturer Award. The department is funded by an Integrative Mammalian Biology (IMB) Capacity Building Award and the NIHR Biomedical Research Centre Funding Scheme.

\section{References}

Ahima RS, Dushay J, Flier SN, Prabakaran D \& Flier JS 1997 Leptin accelerates the onset of puberty in normal female mice. Journal of Clinical Investigation 99 391-395. (doi:10.1172/JCI119172)

Backholer K, Smith J \& Clarke IJ 2009 Melanocortins may stimulate reproduction by activating orexin neurons in the dorsomedial hypothalamus and kisspeptin neurons in the preoptic area of the ewe. Endocrinology 150 5488-5497. (doi:10.1210/en.2009-0604)

Backholer K, Smith JT, Rao A, Pereira A, Iqbal J, Ogawa S, Li Q \& Clarke IJ 2010 Kisspeptin cells in the ewe brain respond to leptin and communicate with neuropeptide Y and proopiomelanocortin cells. Endocrinology 151 2233-2243. (doi:10.1210/en.2009-1190)

Barry J 1979 Immunohistochemistry of luteinizing hormone-releasing hormone-producing neurons of the vertebrates. International Review of Cytology 60 179-221. (doi:10.1016/S0074-7696(08)61263-2)

Bilban M, Ghaffari-Tabrizi N, Hintermann E, Bauer S, Molzer S, Zoratti C, Malli R, Sharabi A, Hiden U, Graier W et al. 2004 Kisspeptin-10, a 
KiSS-1/metastin-derived decapeptide, is a physiological invasion inhibitor of primary human trophoblasts. Journal of Cell Science 117 1319-1328. (doi:10.1242/jcs.00971)

Broberger C, Johansen J, Johansson C, Schalling M \& Hokfelt T 1998 The neuropeptide $\mathrm{Y} /$ agouti gene-related protein (AGRP) brain circuitry in normal, anorectic, and monosodium glutamate-treated mice. PNAS 95 15043-15048. (doi:10.1073/pnas.95.25.15043)

Caraty A, Smith JT, Lomet D, Ben SS, Morrissey A, Cognie J, Doughton B, Baril G, Briant C \& Clarke IJ 2007 Kisspeptin synchronizes preovulatory surges in cyclical ewes and causes ovulation in seasonally acyclic ewes. Endocrinology 148 5258-5267. (doi:10.1210/en.2007-0554)

Castellano JM, Navarro VM, Fernandez-Fernandez R, Nogueiras R, Tovar S, Roa J, Vazquez MJ, Vigo E, Casanueva FF, Aguilar E et al. 2005 Changes in hypothalamic KiSS-1 system and restoration of pubertal activation of the reproductive axis by kisspeptin in undernutrition. Endocrinology 146 3917-3925. (doi:10.1210/en.2005-0337)

Chehab FF, Lim ME \& Lu R 1996 Correction of the sterility defect in homozygous obese female mice by treatment with the human recombinant leptin. Nature Genetics 12 318-320. (doi:10.1038/ng0396-318)

Chehab FF, Mounzih K, Lu R \& Lim ME 1997 Early onset of reproductive function in normal female mice treated with leptin. Science 275 88-90. (doi:10.1126/science.275.5296.88)

Cheung CC, Clifton DK \& Steiner RA 1997 Proopiomelanocortin neurons are direct targets for leptin in the hypothalamus. Endocrinology $\mathbf{1 3 8}$ 4489-4492. (doi:10.1210/en.138.10.4489)

Clarke IJ, Smith JT, Caraty A, Goodman RL \& Lehman MN 2009 Kisspeptin and seasonality in sheep. Peptides 30 154-163. (doi:10.1016/j.peptides. 2008.08.022)

Clarkson J \& Herbison AE 2006 Postnatal development of kisspeptin neurons in mouse hypothalamus; sexual dimorphism and projections to gonadotropin-releasing hormone neurons. Endocrinology 147 5817-5825. (doi:10.1210/en.2006-0787)

Clarkson J, d'Anglemont de Tassigny X, Moreno AS, Colledge WH \& Herbison AE 2008 Kisspeptin-GPR54 signaling is essential for preovulatory gonadotropin-releasing hormone neuron activation and the luteinizing hormone surge. Journal of Neuroscience 28 8691-8697. (doi:10.1523/ JNEUROSCI.1775-08.2008)

Clement K, Vaisse C, Lahlou N, Cabrol S, Pelloux V, Cassuto D, Gourmelen M, Dina C, Chambaz J, Lacorte JM et al. 1998 A mutation in the human leptin receptor gene causes obesity and pituitary dysfunction. Nature 392 398-401. (doi:10.1038/32911)

Clements MK, McDonald TP, Wang R, Xie G, O'Dowd BF, George SR, Austin CP \& Liu Q 2001 FMRFamide-related neuropeptides are agonists of the orphan G-protein-coupled receptor GPR54. Biochemical and Biophysical Research Communications 284 1189-1193. (doi:10.1006/bbrc. 2001.5098)

Coleman DL 1978 Obese and diabetes: two mutant genes causing diabetesobesity syndromes in mice. Diabetologia 14 141-148. (doi:10.1007/ BF00429772)

Cota D, Proulx K, Smith KA, Kozma SC, Thomas G, Woods SC \& Seeley RJ 2006 Hypothalamic mTOR signaling regulates food intake. Science $\mathbf{3 1 2}$ 927-930. (doi:10.1126/science.1124147)

d'Anglemont de Tassigny X, Fagg LA, Dixon JP, Day K, Leitch HG, Hendrick AG, Zahn D, Franceschini I, Caraty A, Carlton MB et al. 2007 Hypogonadotropic hypogonadism in mice lacking a functional Kiss1 gene. PNAS 104 10714-10719. (doi:10.1073/pnas.0704114104)

d'Anglemont de Tassigny X, Fagg LA, Carlton MB \& Colledge WH 2008 Kisspeptin can stimulate gonadotropin-releasing hormone $(\mathrm{GnRH})$ release by a direct action at GnRH nerve terminals. Endocrinology 149 3926-3932. (doi:10.1210/en.2007-1487)

Dhillo WS, Chaudhri OB, Patterson M, Thompson EL, Murphy KG, Badman MK, McGowan BM, Amber V, Patel S, Ghatei MA et al. 2005 Kisspeptin-54 stimulates the hypothalamic-pituitary-gonadal axis in human males. Journal of Clinical Endocrinology and Metabolism 90 6609-6615. (doi:10.1210/jc.2005-1468)

Dhillo WS, Savage P, Murphy KG, Chaudhri OB, Patterson M, Nijher GM, Foggo VM, Dancey GS, Mitchell H, Seckl MJ et al. 2006 Plasma kisspeptin is raised in patients with gestational trophoblastic neoplasia and falls during treatment. American Journal of Physiology. Endocrinology and Metabolism 291 E878-E884. (doi:10.1152/ajpendo.00555.2005)

Dhillo WS, Chaudhri OB, Thompson EL, Murphy KG, Patterson M, Ramachandran R, Nijher GK, Amber V, Kokkinos A, Donaldson M et al. 2007 Kisspeptin-54 stimulates gonadotropin release most potently during the preovulatory phase of the menstrual cycle in women. Journal of Clinical Endocrinology and Metabolism 92 3958-3966. (doi:10.1210/jc.2007-1116)

Dungan HM, Gottsch ML, Zeng H, Gragerov A, Bergmann JE, Vassilatis DK, Clifton DK \& Steiner RA 2007 The role of kisspeptin-GPR54 signaling in the tonic regulation and surge release of gonadotropin-releasing hormone/luteinizing hormone. Journal of Neuroscience 27 12088-12095. (doi:10. 1523/JNEUROSCI.2748-07.2007)

Elchalal U \& Schenker JG 1997 The pathophysiology of ovarian hyperstimulation syndrome - views and ideas. Human Reproduction 12 1129-1137. (doi:10.1093/humrep/12.6.1129)

Farooqi IS, Jebb SA, Langmack G, Lawrence E, Cheetham CH, Prentice AM, Hughes IA, McCamish MA \& O'Rahilly S 1999 Effects of recombinant leptin therapy in a child with congenital leptin deficiency. New England Journal of Medicine 341 879-884. (doi:10.1056/NEJM199909163411204)

Gaytan F, Gaytan M, Castellano JM, Romero M, Roa J, Aparicio B, Garrido N, Sanchez-Criado JE, Millar RP, Pellicer A et al. 2009 KiSS-1 in the mammalian ovary: distribution of kisspeptin in human and marmoset and alterations in KiSS-1 mRNA levels in a rat model of ovulatory dysfunction. American Journal of Physiology. Endocrinology and Metabolism 296 E520-E531. (doi:10.1152/ajpendo.90895.2008)

Goodman RL, Coolen LM, Anderson GM, Hardy SL, Valent M, Connors JM, Fitzgerald ME \& Lehman MN 2004 Evidence that dynorphin plays a major role in mediating progesterone negative feedback on gonadotropin-releasing hormone neurons in sheep. Endocrinology 145 2959-2967. (doi:10.1210/en. 2003-1305)

Goodman RL, Lehman MN, Smith JT, Coolen LM, de Oliveira CV, Jafarzadehshirazi MR, Pereira A, Iqbal J, Caraty A, Ciofi P et al. 2007 Kisspeptin neurons in the arcuate nucleus of the ewe express both dynorphin A and neurokinin B. Endocrinology 148 5752-5760. (doi:10.1210/en.2007-0961)

Gottsch ML, Cunningham MJ, Smith JT, Popa SM, Acohido BV, Crowley WF, Seminara S, Clifton DK \& Steiner RA 2004 A role for kisspeptins in the regulation of gonadotropin secretion in the mouse. Endocrinology 145 4073-4077. (doi:10.1210/en.2004-0431)

Guran T, Tolhurst G, Bereket A, Rocha N, Porter K, Turan S, Gribble FM, Kotan LD, Akcay T, Atay Z et al. 2009 Hypogonadotropic hypogonadism due to a novel missense mutation in the first extracellular loop of the neurokinin B receptor. Journal of Clinical Endocrinology and Metabolism 94 3633-3639. (doi:10.1210/jc.2009-0551)

Gutierrez-Pascual E, Martinez-Fuentes AJ, Pinilla L, Tena-Sempere M, Malagon MM \& Castano JP 2007 Direct pituitary effects of kisspeptin: activation of gonadotrophs and somatotrophs and stimulation of luteinising hormone and growth hormone secretion. Journal of Neuroendocrinology 19 521-530. (doi:10.1111/j.1365-2826.2007.01558.x)

Horikoshi Y, Matsumoto H, Takatsu Y, Ohtaki T, Kitada C, Usuki S \& Fujino M 2003 Dramatic elevation of plasma metastin concentrations in human pregnancy: metastin as a novel placenta-derived hormone in humans. Journal of Clinical Endocrinology and Metabolism 88 914-919. (doi:10.1210/jc. 2002-021235)

Hrabovszky E, Shughrue PJ, Merchenthaler I, Hajszan T, Carpenter CD, Liposits Z \& Petersen SL 2000 Detection of estrogen receptor- $\beta$ messenger ribonucleic acid and 125I-estrogen binding sites in luteinizing hormonereleasing hormone neurons of the rat brain. Endocrinology 141 3506-3509. (doi:10.1210/en.141.9.3506)

Hrabovszky E, Ciofi P, Vida B, Horvath MC, Keller E, Caraty A, Bloom SR, Ghatei MA, Dhillo WS, Liposits Z et al. 2010 The kisspeptin system of the human hypothalamus: sexual dimorphism and relationship with gonadotropin-releasing hormone and neurokinin B neurons. European Journal of Neuroscience 31 1984-1998. (doi:10.1111/j.1460-9568.2010. 07239.x) 
Irwig MS, Fraley GS, Smith JT, Acohido BV, Popa SM, Cunningham MJ, Gottsch ML, Clifton DK \& Steiner RA 2004 Kisspeptin activation of gonadotropin releasing hormone neurons and regulation of KiSS-1 mRNA in the male rat. Neuroendocrinology 80 264-272. (doi:10.1159/000083140)

Janneau JL, Maldonado-Estrada J, Tachdjian G, Miran I, Motte N, Saulnier P, Sabourin JC, Cote JF, Simon B, Frydman R et al. 2002 Transcriptional Expression of genes involved in cell invasion and migration by normal and tumoral trophoblast cells. Journal of Clinical Endocrinology and Metabolism $\mathbf{8 7}$ 5336-5339. (doi:10.1210/jc.2002-021093)

Jayasena CN, Nijher GM, Chaudhri OB, Murphy KG, Ranger A, Lim A, Patel D, Mehta A, Todd C, Ramachandran R et al. 2009 Subcutaneous injection of kisspeptin-54 acutely stimulates gonadotropin secretion in women with hypothalamic amenorrhea, but chronic administration causes tachyphylaxis. Journal of Clinical Endocrinology and Metabolism 94 4315-4323. (doi:10.1210/jc.2009-0406)

Jayasena CN \& Dhillo WS 2010 Neurokinin B and Kisspeptin - sexual partners or single agents? Endocrinology 151 4090-4091. (doi:10.1210/en. 2010-0696)

Jayasena CN, Nijher GMK, Abbara A, Murphy KG, Lim A, Patel DA, Mehta A, Todd C, Donaldson M, Trew G et al. 2010 Twice-weekly administration of kisspeptin-54 for eight weeks stimulates reproductive hormone release in women with hypothalamic amenorrhea, Endo 2010 meeting, San Diego, CA, USA.

Kinoshita M, Tsukamura H, Adachi S, Matsui H, Uenoyama Y, Iwata K, Yamada S, Inoue K, Ohtaki T, Matsumoto H et al. 2005 Involvement of central metastin in the regulation of preovulatory luteinizing hormone surge and estrous cyclicity in female rats. Endocrinology 146 4431-4436. (doi:10.1210/en.2005-0195)

Knobil E, Plant TM, Wildt L, Belchetz PE \& Marshall G 1980 Control of the rhesus monkey menstrual cycle: permissive role of hypothalamic gonadotropin-releasing hormone. Science 207 1371-1373. (doi:10.1126/ science.6766566)

Kotani M, Detheux M, Vandenbogaerde A, Communi D, Vanderwinden JM, Le PE, Brezillon S, Tyldesley R, Suarez-Huerta N, Vandeput F et al. 2001 The metastasis suppressor gene KiSS-1 encodes kisspeptins, the natural ligands of the orphan G protein-coupled receptor GPR54. Journal of Biological Chemistry 276 34631-34636. (doi:10.1074/jbc.M104847200)

Krajewski SJ, Anderson MJ, Iles-Shih L, Chen KJ, Urbanski HF \& Rance NE 2005 Morphologic evidence that neurokinin B modulates gonadotropinreleasing hormone secretion via neurokinin 3 receptors in the rat median eminence. Journal of Comparative Neurology 489 372-386. (doi:10.1002/cne. 20626)

Lee JH, Miele ME, Hicks DJ, Phillips KK, Trent JM, Weissman BE \& Welch DR 1996 KiSS-1, a novel human malignant melanoma metastasissuppressor gene. Journal of the National Cancer Institute 88 1731-1737. (doi:10.1093/jnci/88.23.1731)

Lee DK, Nguyen T, O'Neill GP, Cheng R, Liu Y, Howard AD, Coulombe N, Tan CP, Tang-Nguyen AT, George SR et al. 1999 Discovery of a receptor related to the galanin receptors. FEBS Letters 446 103-107. (doi:10.1016/ S0014-5793(99)00009-5)

Liu X, Lee K \& Herbison AE 2008 Kisspeptin excites gonadotropin-releasing hormone neurons through a phospholipase $\mathrm{C} /$ calcium-dependent pathway regulating multiple ion channels. Endocrinology 149 4605-4614. (doi:10. 1210/en.2008-0321)

Maffei M, Halaas J, Ravussin E, Pratley RE, Lee GH, Zhang Y, Fei H, Kim S, Lallone R, Ranganathan S et al. 1995 Leptin levels in human and rodent: measurement of plasma leptin and ob RNA in obese and weight-reduced subjects. Nature Medicine 1 1155-1161. (doi:10.1038/nm1195-1155)

Mead EJ, Maguire JJ, Kuc RE \& Davenport AP 2007 Kisspeptins are novel potent vasoconstrictors in humans, with a discrete localization of their receptor, $\mathrm{G}$ protein-coupled receptor 54 , to atherosclerosis-prone vessels. Endocrinology 148 140-147. (doi:10.1210/en.2006-0818)

Messager S, Chatzidaki EE, Ma D, Hendrick AG, Zahn D, Dixon J, Thresher RR, Malinge I, Lomet D, Carlton MB et al. 2005 Kisspeptin directly stimulates gonadotropin-releasing hormone release via $\mathrm{G}$ protein-coupled receptor 54. PNAS 102 1761-1766. (doi:10.1073/pnas.0409330102)

Muir AI, Chamberlain L, Elshourbagy NA, Michalovich D, Moore DJ, Calamari A, Szekeres PG, Sarau HM, Chambers JK, Murdock P et al. 2001
AXOR12, a novel human $G$ protein-coupled receptor, activated by the peptide KiSS-1. Journal of Biological Chemistry 276 28969-28975. (doi:10. 1074/jbc.M102743200)

National Institute for Health and Clinical Excellence 2004 Fertility Assessment and Treatment for People with Fertility Problems. http://www.nice.org.uk/nice media/live/10936/29269/29269.pdf.

Navarro VM, Fernandez-Fernandez R, Castellano JM, Roa J, Mayen A, Barreiro ML, Gaytan F, Aguilar E, Pinilla L, Dieguez C et al. 2004 Advanced vaginal opening and precocious activation of the reproductive axis by KiSS-1 peptide, the endogenous ligand of GPR 54. Journal of Physiology 561 379-386. (doi:10.1113/jphysiol.2004.072298)

Navarro VM, Castellano JM, Fernandez-Fernandez R, Tovar S, Roa J, Mayen A, Nogueiras R, Vazquez MJ, Barreiro ML, Magni P et al. 2005 Characterization of the potent luteinizing hormone-releasing activity of KiSS-1 peptide, the natural ligand of GPR54. Endocrinology 146 156-163. (doi:10.1210/en.2004-0836)

Navarro VM, Gottsch ML, Chavkin C, Okamura H, Clifton DK \& Steiner RA 2009 Regulation of gonadotropin-releasing hormone secretion by kisspeptin/dynorphin/neurokinin B neurons in the arcuate nucleus of the mouse. Journal of Neuroscience 29 11859-11866. (doi:10.1523/JNEUROSCI.1569-09.2009)

Nijher G, Chaudhri O, Ramachandran R, Murphy K, Zac-Varghese S, Fowler A, Chinthapalli K, Patterson M, Thompson E, Williamson C et al. 2010 The effects of kisspeptin-54 on blood pressure in humans and plasma kisspeptin levels in hypertensive diseases of pregnancy. British Journal of Clinical Pharmacology 70 674-681. (doi:10.1111/j.1365-2125.2010.03746.x)

Novaira HJ, Ng Y, Wolfe A \& Radovick S 2009 Kisspeptin increases GnRH mRNA expression and secretion in GnRH secreting neuronal cell lines. Molecular and Cellular Endocrinology 311 126-134. (doi:10.1016/j.mce.2009. 06.011)

Ohtaki T, Shintani Y, Honda S, Matsumoto H, Hori A, Kanehashi K, Terao Y, Kumano S, Takatsu Y, Masuda Y et al. 2001 Metastasis suppressor gene KiSS-1 encodes peptide ligand of a G-protein-coupled receptor. Nature 411 613-617. (doi:10.1038/35079135)

Pallais JC, Bo-Abbas Y, Pitteloud N, Crowley WF Jr \& Seminara SB 2006 Neuroendocrine, gonadal, placental, and obstetric phenotypes in patients with IHH and mutations in the G-protein coupled receptor, GPR 54. Molecular and Cellular Endocrinology 254-255 70-77. (doi:10.1016/j.mce. 2006.04.019)

Pelleymounter MA, Cullen MJ, Baker MB, Hecht R, Winters D, Boone T \& Collins F 1995 Effects of the obese gene product on body weight regulation in ob/ob mice. Science 269 540-543. (doi:10.1126/science.7624776)

Pineda R, Garcia-Galiano D, Roseweir A, Romero M, Sanchez-Garrido MA, Ruiz-Pino F, Morgan K, Pinilla L, Millar RP \& Tena-Sempere M 2010 Critical roles of kisspeptins in female puberty and preovulatory gonadotropin surges as revealed by a novel antagonist. Endocrinology 151 722-730. (doi:10.1210/en.2009-0803)

Plant TM, Ramaswamy S \& Dipietro MJ 2006 Repetitive activation of hypothalamic $\mathrm{G}$ protein-coupled receptor 54 with intravenous pulses of kisspeptin in the juvenile monkey (Macaca mulatta) elicits a sustained train of gonadotropin-releasing hormone discharges. Endocrinology 147 1007-1013. (doi:10.1210/en.2005-1261)

Ramaswamy S, Seminara SB, Ali B, Ciofi P, Amin NA \& Plant TM 2010 Neurokinin B stimulates GnRH release in the male monkey (Macaca mulatta) and is colocalized with kisspeptin in the arcuate nucleus. Endocrinology 151 4494-4503. (doi:10.1210/en.2010-0223)

Rance NE 2009 Menopause and the human hypothalamus: evidence for the role of kisspeptin/neurokinin B neurons in the regulation of estrogen negative feedback. Peptides 30 111-122. (doi:10.1016/j.peptides.2008. 05.016)

Rance NE, Young WS III \& McMullen NT 1994 Topography of neurons expressing luteinizing hormone-releasing hormone gene transcripts in the human hypothalamus and basal forebrain. Journal of Comparative Neurology 339 573-586. (doi:10.1002/cne.903390408)

Revel FG, Saboureau M, Masson-Pévet M, Pévet P, Mikkelsen JD \& Simonneaux V 2006 Kisspeptin mediates the photoperiodic control of reproduction in hamsters. Current Biology 16 1730-1735. (doi:10.1016/ j.cub.2006.07.025) 
Revel FG, Ansel L, Klosen P, Saboureau M, Pévet P, Mikkelsen JD \& Simonneaux V 2007 Kisspeptin: a key link to seasonal breeding. Reviews in Endocrine and Metabolic Disorders 8 57-65. (doi:10.1007/ s11154-007-9031-7)

Richard N, Galmiche G, Corvaisier S, Caraty A \& Kottler ML 2008 KiSS-1 and GPR54 genes are co-expressed in rat gonadotrophs and differentially regulated in vivo by oestradiol and gonadotrophin-releasing hormone. Journal of Neuroendocrinology 20 381-393. (doi:10.1111/j.1365-2826.2008. 01653.x)

Roa J, Vigo E, Castellano JM, Navarro VM, Fernandez-Fernandez R, Casanueva FF, Dieguez C, Aguilar E, Pinilla L \& Tena-Sempere M 2006 Hypothalamic expression of KiSS-1 system and gonadotropin-releasing effects of kisspeptin in different reproductive states of the female rat. Endocrinology 147 2864-2878. (doi:10.1210/en.2005-1463)

Roa J, Vigo E, Castellano JM, Gaytan F, Navarro VM, Aguilar E, Dijcks FA, Ederveen AG, Pinilla L, van Noort PI et al. 2008 Opposite roles of estrogen receptor (ER)- $\alpha$ and ER $\beta$ in the modulation of luteinizing hormone responses to kisspeptin in the female rat: implications for the generation of the preovulatory surge. Endocrinology 149 1627-1637. (doi:10.1210/en. 2007-1540)

Roa J, Garcia-Galiano D, Varela L, Sanchez-Garrido MA, Pineda R, Castellano JM, Ruiz-Pino F, Romero M, Aguilar E, Lopez M et al. 2009 The mammalian target of rapamycin as novel central regulator of puberty onset via modulation of hypothalamic Kiss1 system. Endocrinology 150 5016-5026. (doi:10.1210/en.2009-0096)

Rometo AM, Krajewski SJ, Voytko ML \& Rance NE 2007 Hypertrophy and increased kisspeptin gene expression in the hypothalamic infundibular nucleus of postmenopausal women and ovariectomized monkeys. Journal of Clinical Endocrinology and Metabolism 92 2744-2750. (doi:10.1210/jc.2007-0553)

Roseweir AK, Kauffman AS, Smith JT, Guerriero KA, Morgan K, PieleckaFortuna J, Pineda R, Gottsch ML, Tena-Sempere M, Moenter SM et al. 2009 Discovery of potent kisspeptin antagonists delineate physiological mechanisms of gonadotropin regulation. Journal of Neuroscience $\mathbf{2 9}$ 3920-3929. (doi:10.1523/JNEUROSCI.5740-08.2009)

de Roux N, Genin E, Carel JC, Matsuda F, Chaussain JL \& Milgrom E 2003 Hypogonadotropic hypogonadism due to loss of function of the KiSS1derived peptide receptor GPR54. PNAS 100 10972-10976. (doi:10.1073/ pnas.1834399100)

Schmelzle T \& Hall MN 2000 TOR, a central controller of cell growth. Cell $103253-262$.

Seminara SB, Messager S, Chatzidaki EE, Thresher RR, Acierno JS Jr, Shagoury JK, Bo-Abbas Y, Kuohung W, Schwinof KM, Hendrick AG et al. 2003 The GPR54 gene as a regulator of puberty. New England Journal of Medicine 349 1614-1627. (doi:10.1056/NEJMoa035322)

Seminara SB, Dipietro MJ, Ramaswamy S, Crowley WF Jr \& Plant TM 2006 Continuous human metastin 45-54 infusion desensitizes $\mathrm{G}$ protein-coupled receptor 54-induced gonadotropin-releasing hormone release monitored indirectly in the juvenile male Rhesus monkey (Macaca mulatta): a finding with therapeutic implications. Endocrinology 147 2122-2126. (doi:10.1210/ en.2005-1550)

Shahab M, Mastronardi C, Seminara SB, Crowley WF, Ojeda SR \& Plant TM 2005 Increased hypothalamic GPR 54 signaling: a potential mechanism for initiation of puberty in primates. PNAS 102 2129-2134. (doi:10.1073/ pnas.0409822102)

Silverman AJ, Antunes JL, Ferin M \& Zimmerman EA 1977 The distribution of luteinizing hormone-releasing hormone (LHRH) in the hypothalamus of the rhesus monkey. Light microscopic studies using immunoperoxidase technique. Endocrinology 101 134-142. (doi:10.1210/endo-101-1-134)
Smith JT, Cunningham MJ, Rissman EF, Clifton DK \& Steiner RA 2005 Regulation of Kiss 1 gene expression in the brain of the female mouse. Endocrinology 146 3686-3692. (doi:10.1210/en.2005-0488)

Smith JT, Acohido BV, Clifton DK \& Steiner RA 2006a KiSS-1 neurones are direct targets for leptin in the ob/ob mouse. Journal of Neuroendocrinology 18 298-303. (doi:10.1111/j.1365-2826.2006.01417.x)

Smith JT, Popa SM, Clifton DK, Hoffman GE \& Steiner RA $2006 b$ Kiss 1 neurons in the forebrain as central processors for generating the preovulatory luteinizing hormone surge. Journal of Neuroscience $\mathbf{2 6}$ 6687-6694. (doi:10.1523/JNEUROSCI.1618-06.2006)

Smith JT, Rao A, Pereira A, Caraty A, Millar RP \& Clarke IJ 2008 Kisspeptin is present in ovine hypophysial portal blood but does not increase during the preovulatory luteinizing hormone surge: evidence that gonadotropes are not direct targets of kisspeptin in vivo. Endocrinology 149 1951-1959. (doi:10.1210/en.2007-1425)

Teles MG, Bianco SD, Brito VN, Trarbach EB, Kuohung W, Xu S, Seminara SB, Mendonca BB, Kaiser UB \& Latronico AC 2008 A GPR54-activating mutation in a patient with central precocious puberty. New England Journal of Medicine 358 709-715. (doi:10.1056/NEJMoa073443)

Thompson EL, Patterson M, Murphy KG, Smith KL, Dhillo WS, Todd JF, Ghatei MA \& Bloom SR 2004 Central and peripheral administration of kisspeptin-10 stimulates the hypothalamic-pituitary-gonadal axis. Journal of Neuroendocrinology 16 850-858. (doi:10.1111/j.1365-2826.2004. 01240.x)

Todman MG, Han SK \& Herbison AE 2005 Profiling neurotransmitter receptor expression in mouse gonadotropin-releasing hormone neurons using green fluorescent protein-promoter transgenics and microarrays. Neuroscience 132 703-712. (doi:10.1016/j.neuroscience.2005.01.035)

Topaloglu AK, Reimann F, Guclu M, Yalin AS, Kotan LD, Porter KM, Serin A, Mungan NO, Cook JR, Ozbek MN et al. 2009 TAC3 and TACR 3 mutations in familial hypogonadotropic hypogonadism reveal a key role for neurokinin B in the central control of reproduction. Nature Genetics 41 354-358. (doi:10.1038/ng.306)

Welt CK, Chan JL, Bullen J, Murphy R, Smith P, DePaoli AM, Karalis A \& Mantzoros CS 2004 Recombinant human leptin in women with hypothalamic amenorrhea. New England Journal of Medicine 351 987-997. (doi:10.1056/NEJMoa040388)

Wintermantel TM, Campbell RE, Porteous R, Bock D, Grone HJ, Todman MG, Korach KS, Greiner E, Perez CA, Schutz G et al. 2006 Definition of estrogen receptor pathway critical for estrogen positive feedback to gonadotropin-releasing hormone neurons and fertility. Neuron $\mathbf{5 2} 271-280$. (doi:10.1016/j.neuron.2006.07.023)

Wu M, Dumalska I, Morozova E, van den PA \& Alreja M 2009 Melaninconcentrating hormone directly inhibits $\mathrm{GnRH}$ neurons and blocks kisspeptin activation, linking energy balance to reproduction. PNAS 106 17217-17222. (doi:10.1073/pnas.0908200106)

Zhang Y, Proenca R, Maffei M, Barone M, Leopold L \& Friedman JM 1994 Positional cloning of the mouse obese gene and its human homologue. Nature 372 425-432. (doi:10.1038/372425a0)

Received in final form 8 November 2010
Accepted 17 November 2010
Made available online as an Accepted Preprint
17 November 2010

Received in final form 8 November 2010 Made available online as an Accepted Preprint 17 November 2010 